\title{
Feasibility of Mechanical Properties of Lamina Hybrid Composite Ramie Fiber-Coconut Fiber-Fiberglass as an Alternative Hull Substitution of Material Structure Under 25M-V Type
}

\author{
Mohammad Galbi*, Lomo Mula Tua, Arif Rahman Hakim \\ Faculty of Engineering, Mechanical Engineering, Universitas Pembangunan Nasional Veteran Jakarta, Indonesia
}

\begin{abstract}
The use of metals in ship components is increasingly reduced, this is because the metal has a heavy weight, a difficult manufacturing process, and easy to corrode. The ship components began to use non-metallic materials, such as composites. Composites commonly used in ship hull construction are fiberglass composites, this material is chosen because this material has strong, lightweight, rustproof and easy manufacturing processes. Fiberglass is a non-renewable material, so development needs to be done, one of them by utilizing natural fibers. The selected natural fibers are ramie fiber and coconut fiber, the choice of this material is based on the availability of abundant material and good mechanical properties. Then the specimen was made using a hand lay-up manufacturing method with a composition of the G-SSK$\mathrm{SR} 90^{\circ}$ and $\mathrm{G} 90^{\circ}$ layer with BTQN 157 printed polyester, which was then subjected to tensile testing. From the test results it is known that the maximum tensile strength of the $\mathrm{G} 90^{\circ}$ composite is more optimal than the G-SSK-SR $90^{\circ}$ layer composite. Then the results of static simulation based on engineering thickness with the manufacturing method of these two composite variations can be declared feasible based on BKI mechanical standards and safety factor values.
\end{abstract}

Keywords: Mechanical Properties, Lamina Hybrid Composite, Material Structure

\section{Introduction}

The use of composites at this time is widely applied to marine ship construction structures, especially in the hull part of the ship because the use of composite materials can make optimal weight efficiency, but has high strength and stiffness. Composite material that is commonly used in marine boat hulls is fiberglass, fiberglass is widely used for ship hull construction because of its strong, lightweight, tough, rust-resistant, relatively economical, and easy manufacturing process, but fiberglass is a non-renewable material. difficult to decompose when it is not suitable for use, and the production still depends on exports.

There is a need for sustainable development of raw materials for composite reinforcing fillers that are environmentally friendly and renewable, such as natural fibers whose utilization has not been maximized and has not been intensified massively in Indonesia. This alternative material has several advantages, namely easy to obtain, low economic value, environmentally friendly and renewable. In this study, the alternative materials used were hemp fiber and coconut fiber as composite reinforcing fillers with a manufacturing process using the hand lay up method for the manufacture of ship hulls. Utilization of hemp and coconut fibers is expected to reduce production costs for ship hull construction and increase natural resources, especially natural fiber, which is one of the alternative materials that can support fiberglass fillers for composite strength. The purpose of this study focuses on the types of variations. the most optimal sample based on the average tensile test results to determine the thickness according to BKI mechanical standards, material safety factor values, and manufacturing methods that match the criteria. Based on the results of this study, it is expected to be a breakthrough in terms of innovative material technology developments, especially in the maritime industry.

\section{Materials and Methods}

\subsection{Design of Test Specimens}

In accordance with the rules used by BKI 2015, the test specimens follow ISO 527 - 4. Dimensional planning of tensile test specimens according to the drawing.

\footnotetext{
* Corresponding author: galbi_m@upnvj.ac.id.
} 

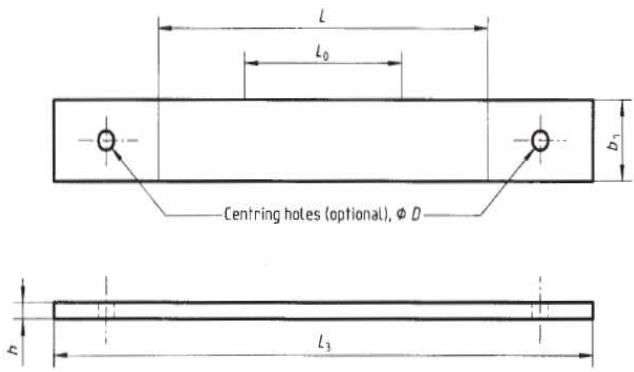

a) Type 2 specimen

Fig.1. ISO 527-4 Specimen Design

\subsection{Composite Composition}

The composition for the lamination process refers to the standards of the Indonesian Classification Bureau, in

Table 1. Comparison of composite compositions

\begin{tabular}{ccc}
\hline Type of Laminate & Material & Comparison of Resin/(Kg) \\
\hline Fiber Lamination & -Katalis & $(1 \mathrm{~s} / \mathrm{d} 1,5) \%$, certain condition $2 \%$ \\
& -CSM300 & $(0,9-1,0) \mathrm{kg} / \mathrm{m}^{2}$ \\
& -CSM450 & $(1,1-1,2) \mathrm{kg} / \mathrm{m}^{2}$ \\
& -WR600 & $(1,5-1,6) \mathrm{kg} / \mathrm{m}^{2}$ \\
& -SSK & $(0,9-1,0) \mathrm{kg} / \mathrm{m}^{2}$ \\
Gelcoat & -SR & $(0,9-1,0) \mathrm{kg} / \mathrm{m}^{2}$ \\
& -Pigmen & $(8-10) \%$ \\
& -Aerosil & $(0,6-1,0) \%$ \\
& -Kobalt & $(1,0-1,5) \%$ \\
\hline
\end{tabular}

Table 2. Planning layer data

\begin{tabular}{lll}
\hline \multicolumn{1}{c}{ Item } & \multicolumn{1}{c}{ Natural Fiber } & \multicolumn{1}{c}{ Synthetic Fiber } \\
\hline Layer & $\left(\mathrm{G}+\mathrm{CSM}_{300}+\mathrm{CSM}_{450}+\mathrm{SR}+\right.$ & $\left(\mathrm{G}+\mathrm{CSM}_{300}+\mathrm{CSM}_{450}+\mathrm{WR}_{600}+\right.$ \\
Composition & $\left.\mathrm{SSK}+\mathrm{SR}+\mathrm{CSM}_{450}+\mathrm{CSM}_{300}\right)$ & $\begin{array}{l}\mathrm{CSM}_{450}+\mathrm{WR}_{600}+\mathrm{CSM}_{450}+ \\
\left.\mathrm{CSM}_{300}\right) \\
\text { Thickness }(\mathrm{mm})\end{array}$ \\
\hline
\end{tabular}

a. Composite Tensile Testing Results Data G-SSK-SR

\subsection{Design of Test Specimens Static Stress Analysis Simulation Stages}

In this study, a static stress simulation was carried out on the hull design, this was done to determine the critical point and maximum stress on the hull, where the maximum stress results would be compared with the maximum tensile stress of the test results. Later the results of this simulation are used as a reference for determining safe limits apart from BKI mechanical standards. For the Static Stress simulation using Solidwork 2018 software.

\section{Result and Disscussion}

\subsection{Design Mechanical Testing Result Data}

Following are the results of the tensile test as shown in the graph and visual of the fracture of the specimen according to the pictures and drawings this study for the composition of the composition ratio of natural fiber alloys following the mass / $\mathrm{m} 2$ that is fibers.[9]

\subsection{Planning Layer}

Table 2, shown a plnning layer data, composition and thickness of natural fiber and synthetic fiber. The description of material ar as follow : $\mathrm{G}=$ Gelcoat, CSM = Chopped Strand Matting 300c, CSM $450=$ Chopped Strand Matting 450, WR600 = Woven Roving $600, \mathrm{SSK}=$ Coconut Coir Fiber and SR $=$ Hemp Fiber closest to the standard composition for synthetic $90^{\circ}$

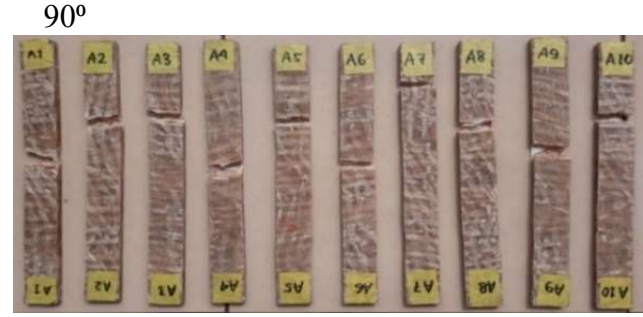

Fig.2. Visual Fracture Results of G-SSK-SR $90^{\circ}$ Composite Spesimens 
Table 3. Thickness Manipulation Data

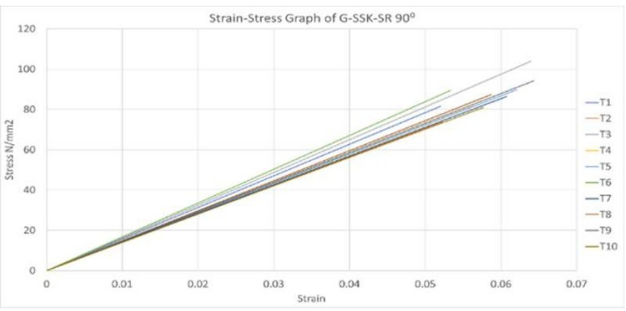

Fig 3. Stress and Strain Graph of G-SSK-SR $90^{\circ}$ Composites

Based on the graph of the test results of 10 samples of composite specimen G-SSK-SR $90^{\circ}$, it is known that the maximum average stress is $28.95 \pm 1.55104982 \mathrm{MPa}$ with an average modulus of elasticity of 767.4973489 $\mathrm{MPa}$

b. G $90^{\circ}$ Composite Tensile Testing Results Data

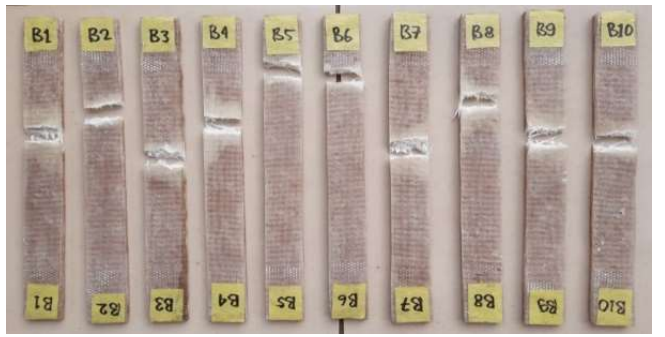

Fig.4. Visual Fracture Results of $\mathrm{G} 90^{\circ}$ Composite Spesimens

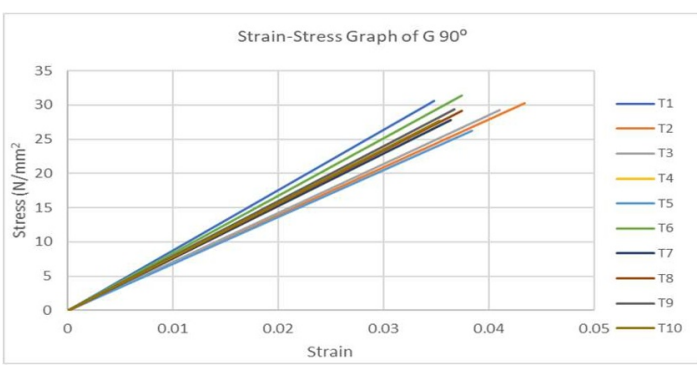

Fig.5. Stress and Strain Graph of G $90^{\circ}$ Composites

Based on the graph of the test results of 10 samples of composite specimen $\mathrm{G} 90^{\circ}$, it is known that the maximum average stress is $86.93 \pm 8.27799788 \mathrm{MPa}$ with an average modulus of elasticity of $767.4973489 \mathrm{Mpa}$.

\subsection{Design Planning for Optimization of Tensile Strength Based on Composite Thickness}

Based on the results of the tensile test, it is known that the test results do not meet the mechanical standards set. So to get the optimal tensile strength and elastic modulus, one way that can be done is to engineer the thickness of the composite, the thickness of the composite is planned to achieve the mechanical standards set by the Indonesian Classification Bureau, where the thickness engineering is calculated based on the primary data from the tensile test results.

\begin{tabular}{|c|c|c|}
\hline $\begin{array}{l}\text { Thickness } \\
\text { manipulation }\end{array}$ & $\begin{array}{c}\text { Ultimate } \\
\text { Tensile } \\
\text { Strength } \\
\text { (MPa) }\end{array}$ & $\begin{array}{c}\text { Elastic } \\
\text { Modulus } \\
(\mathrm{MPa})\end{array}$ \\
\hline 54,747 & 228,705 & 6063,229056 \\
\hline 26,733 & 349,47468 & 6012,984859 \\
\hline
\end{tabular}

\subsection{Internal and External Factors in Static Hull Simulation}

In the simulation process, the internal factors are obtained from the ship's cargo and the installation installed on the casco body, where it is known that the load obtained is $3671 \mathrm{~N}$ for $0 \%$ DWT load, $10022.95 \mathrm{~N}$ for $50 \%$ DWT load, and $15493.8 \mathrm{~N}$ for $100 \%$ DWT load. For the external factors obtained from the design pressure calculation at the hull bottom are known to be the bottom impact pressure $0.01034588378 \mathrm{MPa}$ for $0 \%$ DWT load, $0.01067147991 \mathrm{MPa}$ for $50 \%$ DWT load, and $0.01059947323 \mathrm{MPa}$ for $50 \%$ DWT load.

\subsection{Design Static Analysis of Hull with Variation of Load}

This analysis is tested based on the primary data from the test results that have been processed by the author so that the data is the parameter in carrying out a static simulation on Solidwork 2018 software, then this data is then inputted into the simulation software, using Static Simulation.

In this static simulation, it only refers to the engineering thickness of each variation, the load load and the bottom impact pressure. The simulation results are stress, strain at each loading variation.

Composite analysis of G-SSK-SR 90 variation on Hull with Variation of Load

\subsubsection{Static analysis at 0\% DWT loading}

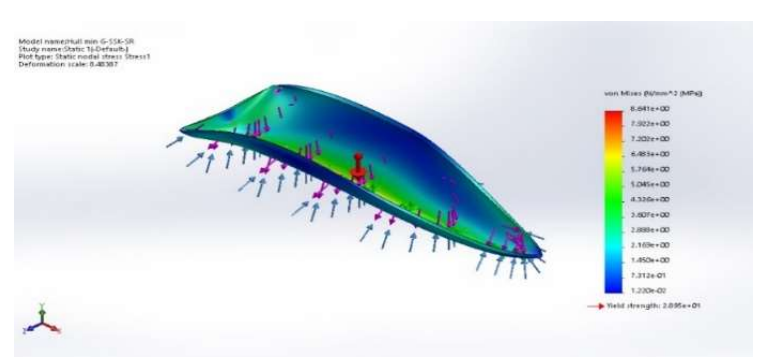

Fig.6. Visual stress result for the G-SSK-SR $90^{\circ}$ composite on a static simulation of $100 \%$ DWT loading

The simulation results under $0 \%$ DWT loading conditions at a water-laden height of $0.29 \mathrm{~m}$ and a hull thickness of $55 \mathrm{~mm}$ obtained a maximum stress of 8,641 MPa that occurs in the keel section, then the minimum stress occurs on the side hull section of $0.0122 \mathrm{MPa}$. 


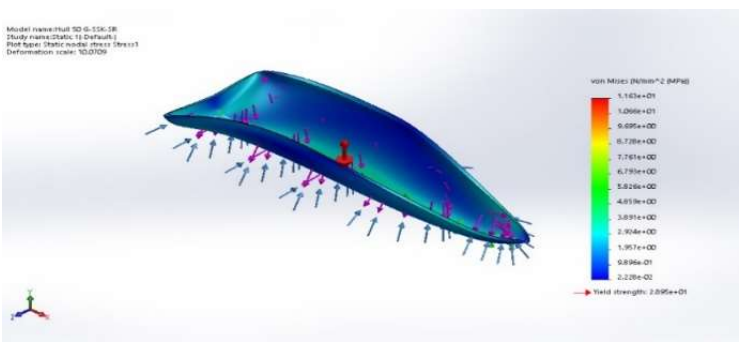

Fig.7. Visual strain result for the G-SSK-SR $90^{\circ}$ composite on a static simulation of $0 \%$ DWT loading

The simulation results at $0 \%$ DWT loading conditions at a water-laden height of $0.29 \mathrm{~m}$ and a hull thickness of $55 \mathrm{~mm}$ obtained a maximum strain of 0.005982 that occurs in the keel section, then the minimum strain occurs in the side hull section of 0.00002303.2) Static analysis at 50\% DWT loading



Fig.8. Visual stress result for the G-SSK-SR $90^{\circ}$ composite on a static simulation of $50 \%$ DWT loading

The simulation results under 50\% DWT loading conditions at a water-laden height of $0.35 \mathrm{~m}$ and a hull thickness of $55 \mathrm{~mm}$, the maximum stress is $11.63 \mathrm{MPa}$ which occurs in the keel section, then the minimum stress occurs on the side hull section of $0.02228 \mathrm{MPa}$.

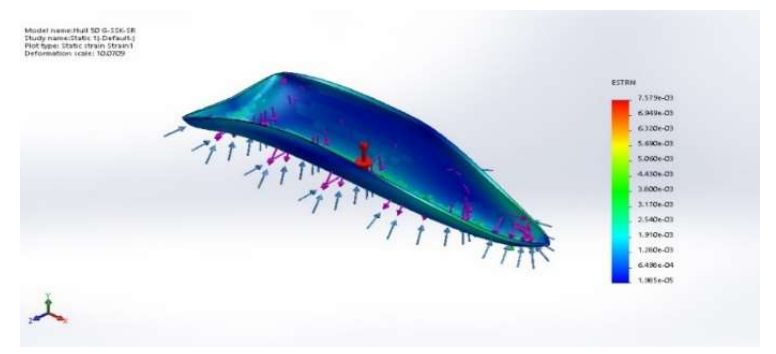

Fig.9. Visual strain result for the G-SSK-SR $90^{\circ}$ composite on a static simulation of 50\% DWT loading

The simulation results under $50 \%$ DWT loading conditions at a water-laden height of $0.35 \mathrm{~m}$ and a hull thickness of $55 \mathrm{~mm}$ obtained a maximum strain of 0.007579 that occurs in the keel section, then the minimum strain occurs on the side hull section of 0.00001985

\subsubsection{Static analysis at $100 \%$ DWT loading}

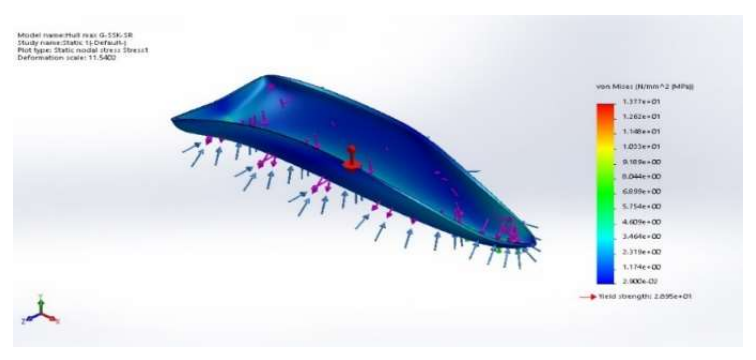

Fig.10. Visual stress result for the G-SSK-SR $90^{\circ}$ composite on a static simulation of $100 \%$ DWT loading

The simulation results under $100 \%$ DWT loading conditions at a water-laden height of $0.4 \mathrm{~m}$ and a hull thickness of $55 \mathrm{~mm}$, the maximum stress is $13.77 \mathrm{MPa}$ which occurs in the keel section, then the minimum stress occurs on the side hull section of $0.02900 \mathrm{MPa}$.

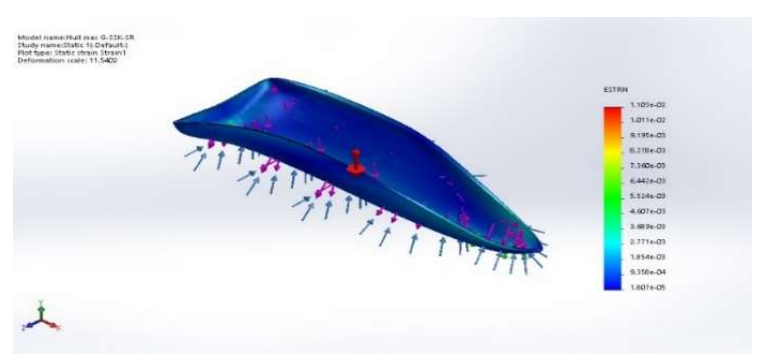

Fig.11. Visual strain result for the G-SSK-SR $90^{\circ}$ composite on a static simulation of $100 \%$ DWT loading

The simulation results under $100 \%$ DWT loading conditions at a water-laden height of $0.4 \mathrm{~m}$ and a hull thickness of $55 \mathrm{~mm}$ obtained a maximum strain of 0.0103 that occurs in the keel section, then the minimum strain occurs in the side hull section of 0.00001807 .

Composite analysis of variation $\mathrm{G} 90^{\circ}$ on Hull with Variation of Load

1) Static analysis at $0 \%$ DWT loading

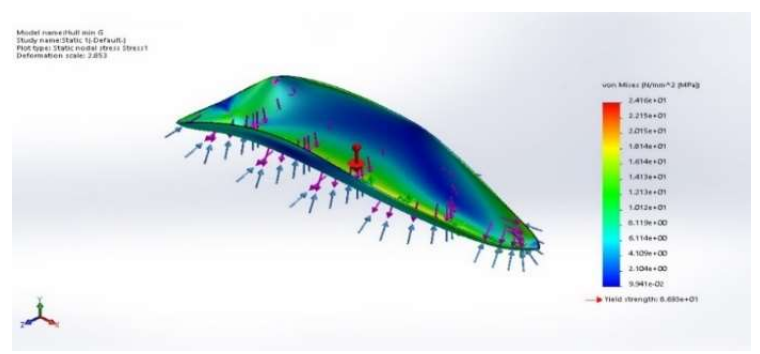

Fig. 12. Visual stress result for the $\mathrm{G} 90^{\circ}$ composite on a static simulation of $100 \%$ DWT loading

The simulation results at $0 \%$ DWT loading conditions at a water-laden height of $0.29 \mathrm{~m}$ and a hull thickness of $27 \mathrm{~mm}$ obtained a maximum stress of $24.16 \mathrm{MPa}$ that occurs in the keel section, then the minimum stress occurs on the side hull section of $0.09941 \mathrm{MPa}$. 


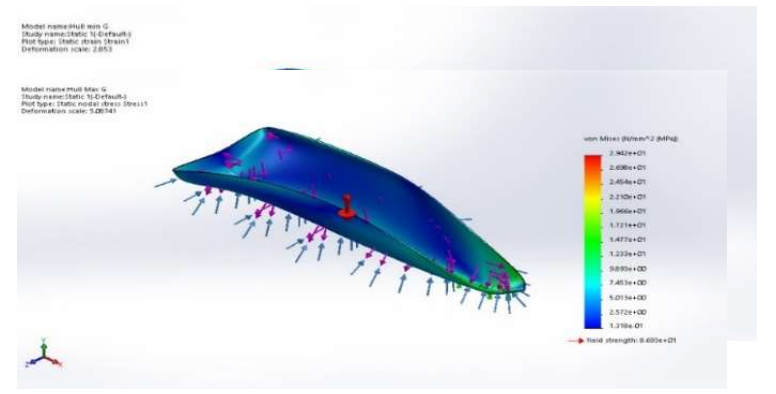

Fig.13. Visual strain result for the $\mathrm{G} 90^{\circ}$ composite on a static simulation of $0 \%$ DWT loading

The simulation results at $0 \%$ DWT loading conditions at a water-laden height of $0.29 \mathrm{~m}$ and a hull thickness of $27 \mathrm{~mm}$ obtained a maximum strain of 0.007669 that occurs in the keel section, then the minimum strain occurs in the side hull section of 0.00004771 .

\subsubsection{Static analysis at 50\% DWT loading}

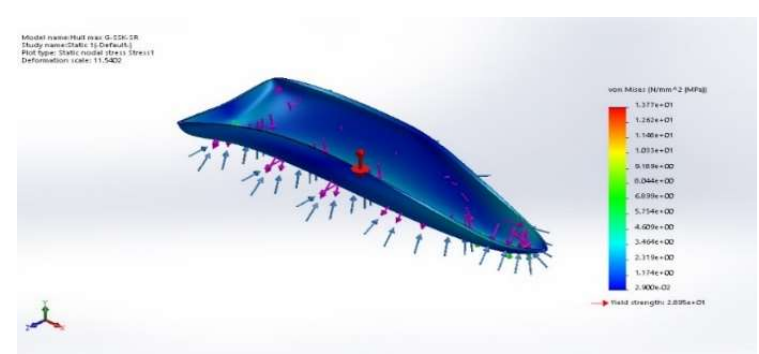

Fig.14. Visual stress result for the $\mathrm{G} 90^{\circ}$ composite on a static simulation of $50 \%$ DWT loading

The simulation results under 50\% DWT loading conditions at a water-laden height of $0.35 \mathrm{~m}$ and a hull thickness of $27 \mathrm{~mm}$, the maximum stress is $27.99 \mathrm{MPa}$ that occurs in the keel section, then the minimum stress occurs on the side hull section of $0.1549 \mathrm{MPa}$.

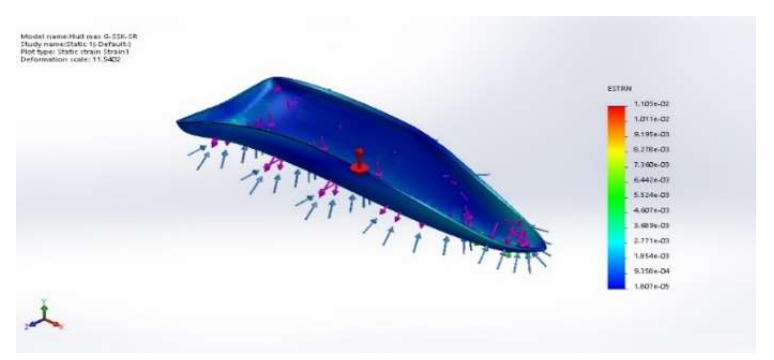

Fig.15. Visual strain result for the $\mathrm{G} 90^{\circ}$ composite on a static simulation of $50 \%$ DWT loading

The simulation results under 50\% DWT loading conditions at a water-laden height of $0.35 \mathrm{~m}$ and a hull thickness of $27 \mathrm{~mm}$ obtained a maximum strain of 0.00913 that occurs in the keel section, then the minimum strain occurs in the side hull section of 0.00004213 .

\subsection{Design Safety Factor Analysis on each Load Variation}

The safety factor is calculated based on the maximum tensile strength of the test results divided by the working stress based on the simulation :

Table 4. Table of composite safety factor for variation of G-SSK-SR $90^{\circ}$

\begin{tabular}{ccccc}
\hline $\begin{array}{c}\text { Load } \\
\text { Condition }\end{array}$ & $\begin{array}{c}\text { Max } \\
\text { Stress } \\
(\mathrm{MPa})\end{array}$ & $\begin{array}{c}\text { Yield } \\
\text { Stress } \\
(\mathrm{MPa})\end{array}$ & $\begin{array}{c}\text { Safety } \\
\text { Factor }\end{array}$ & Where \\
\hline $\begin{array}{c}0 \% \text { DWT } \\
\text { Loading }\end{array}$ & 8,64 & 28,95 & 3,35 & Allowed \\
\hline $\begin{array}{c}50 \% \text { DWT } \\
\text { Loading }\end{array}$ & 11,63 & 28,95 & 2,50 & Allowed \\
\hline $\begin{array}{c}100 \% \text { DWT } \\
\text { Loading }\end{array}$ & 13,77 & 28,95 & 2,1 & Allowed \\
\hline Average & 11,35 & 28,95 & 2,65 & Allowed
\end{tabular}

Of the three loading factors that refer to the hull simulation results using the G-SSK-SR $90^{\circ}$ material, it meets the safety limit criteria.

Table 5. Table of composite safety factor variation $\mathrm{G} 90^{\circ}$

\begin{tabular}{ccccc}
\hline $\begin{array}{c}\text { Load } \\
\text { Condition }\end{array}$ & $\begin{array}{c}\text { Max } \\
\text { Stress } \\
(\mathrm{MPa})\end{array}$ & $\begin{array}{c}\text { Yield } \\
\text { Stress } \\
(\mathrm{MPa})\end{array}$ & $\begin{array}{c}\text { Safety } \\
\text { Factor }\end{array}$ & Where \\
\hline $\begin{array}{c}\text { 0\% DWT } \\
\text { Loading }\end{array}$ & 24,16 & 86,93 & 3,60 & Allowed \\
\hline $\begin{array}{c}50 \% \\
\text { DWT } \\
\text { Loading }\end{array}$ & 27,99 & 86,93 & 3,10 & Allowed \\
\hline $\begin{array}{c}100 \% \\
\text { DWT }\end{array}$ & 29,42 & 86,93 & 2,95 & Allowed \\
Loading & & & & \\
\hline Average & 31.3653 & 86,93 & 3,22 & Allowed \\
\hline
\end{tabular}

Of the three loading factors that refer to the hull simulation results using $\mathrm{G} 90^{\circ}$ material, it has met the safety limit criteria.

\section{Conclusion}

Through the use of spatial analysis such as topographic operations, proximity calculation, buffer construction, raster reclassification, and intersection operations, GISbased studies may be beneficial in a broad variety of disaster assessment applications including Tsunami vulnerability. The susceptibility to tsunamis varied according to slope, elevation, land use, distance from the shore, and distance from the river in the studied regions. The area designated as very vulnerable covered 157,10 hectares. These locations may have sustained the most damage from a tsunami catastrophe due to their proximity to the sea, low terrain and slope, and dense population. In consideration of the tsunami disasters in Aceh, we anticipate that tsunami risk maps will support 
in the initiation of humanitarian and development activities in North Maluku Province.

\section{References}

[1] Gibson F. R, (1994), 'Principles of Composite Material Mechanics', McGraw-Hill, Inc, Michigan.Askeland (1985) 'The Science And Engineering of Materials

[2] Berthelot, J.M., 1999. 'Composite Materials : Mechanical Behaviour and Structural Analysis. Imprint New York : Springer . Series : Mechanical Engineering (Berlin, Germany. ISSBN-13 : 9780387984261.

[3] Mussig, J, (2010), 'Industrial Aplication of Natural Fibres', A John Wiley and Sons, Ltd., Publication, Bremen, Germany.

[4] Purboputro, P. I, Hariyanto, A (2017), 'Analisa Sifat Tarik dan Impak Komposit Serat Rami dengan Perlakuan Alkali dalam Waktu 2, 4, 6 dan 8 Jam Bermatrik Poliester', Media Mesin: Jurnal Ilmiah Teknik Mesin Vol. 18 No. 2 Juli 2017: 6475.

[5] Hermawan, D. (2017), 'Analisa Sifat Mekanik Serat Kelapa Pada Material Komposit', Prosiding UNMUHPNK.

[6] Askeland (1985) 'The Science and Engineering of Materials'

[7] Biro Klasifikasi, 2013 Edition. 'Rules for Small Vessel Up To 24M'. Vol VII, Jakarta.

[8] Biro Klasifikasi, 2019. 'Rules for Classification and Surveys', Vol I, Jakarta.

[9] Marasabessy, A, Nur, I, \& Sudjasta, B. (2014), 'Metode Pemeliharaan Yang Tepat Lambung Kapal Type Patroli V30 Berbahan Fiberglass', BINA WIDYA, Vol 25 No. 2, Edisi Mei 2014 : 5756. 